№ 10. - С. 102-105. 6. Личность и её формирование в процессе физического воспитания [Електронний ресурс]. - Режим доступа: http:www.ns-sport.ru/lichnost-s-eeformirovanie-v-processe-fizicgeskogo-vospitaniyapage-25.html.

7. Нечипоренко Л. А. Формування особистісних досягнень підлітків у процесі фізичного виховання/ Л. А. Нечипоренко // Педагогіка, психологія та медико-біологічні проблеми фізичного виховання і спорту : зб. наук. пр. / за ред. Срмакова С. С. - Х. : ХДАДМ, - 2010. №4. - С. 104-107. 8. Пивовар А. А. Поєднаний розвиток фізичних і пізнавальних здібностей дітей 5 і 6 років у процесі фізичного виховання: автореф. дис. на здобуття наук. ступеня канд. наук 3 фізичного виховання і спорту: 24.00.02. «Фізична культура, фізичне виховання різних груп населення» / А. А. Пивовар. - Львів, 2005. 24 с. 9. Родин М. А. Формирование личности старших подростков в условиях учебнотренировочного процесса / М. А. Родин // Физическая культура: научно-методический журнал. - 2003. - №4. - С. 15-18. 10. Шкабура О. Н. Формування ціннісних орієнтацій першокласників [Електронний ресурс]/ О.Н. Шкабура. - 2013. - Режим доступу : http//osvita.ua/school/lessons_summaupbring/34366/.

УДК 373.41

Світлана Якименко

\title{
ІНТЕГРАЦЙНІ ПРОЦЕСИ В СУЧАСНІЙ ПОЧАТКОВІЙ ОСВІТІ
}

Якименко С. І. Інтеграційні процеси в сучасній початковій освіті.

У статті розглянуто питання інтеграційних процесів у сучасній початковій школі: проблеми та перспективи. Проаналізовано головні аспекти, причини i тенденції розвитку інтеграційних процесів, що безпосередньо стосуються змісту початкової освіти.

Ключові слова: інтеграція, інтеграційні процеси, початкова школа, навчання.

Якименко С. И. Интеграционные процессы в современном начальном образовании.

В статье автор рассматривает вопрос интеграционных процессов в современной начальной школе: проблемы и перспективы. Анализирует главные аспекты, причины и тенденции развития интеграционных процессов, которые непосредственно касаются содержания начального образования.

Ключевые слова: интеграция, интеграционные процессы, начальная школа, учеба.

Yakymenko S. I. Integration processes in modern primary education.

In this article the author considers questions of integration processes in the modern primary school : problems and prospects. The author analyzes the main aspects, reasons and tendencies of development of integration processes that relate directly to the contents of primary education.

Key words: Integration, integration processes, primary school, education.

Інтеграційні процеси в освіті - явище досить складне, комплексне і різнобічне за різновидами свого вияву, яке вимагає аналізу психологічної й педагогічної позицій.

Основна мета навчання на інтегративній основі - надати цілісне уявлення про навколишній світ - пов'язана 3 підвищенням розумової активності учнів, а отже, необхідне визначення психофізіологічних основ інтеграції знань, чітке уявлення про 
фактичні особливості розвитку в дитинстві основних мисленневих дій.

Психофізіологічне обгрунтування механізму оволодіння знаннями і процесу їх інтеграції нам уявляється можливим на підставі двох психологічних концепцій теорії поетапного формування розумових дій (П. Гальперін, А. Леонтьєв, Н. Тализіна) й асоціативно-рефлекторної природи розумової діяльності (Є. Кабанова-Меллер, Н. Менчинська, Ю. Самарін).

Meта статті - проаналізувати головні аспекти, причини і тенденції розвитку інтеграційних процесів, що безпосередньо стосуються змісту початкової освіти.

Значення інтеграційних процесів Н. Тализіна [6] вбачає вже у власне психофізіологічному механізмі поетапного переходу представлених у матеріальній i матеріалізованій формі відомостей зовнішнього плану у внутрішній, розумовий план у процесі поетапного формування розумових дій. Окреслена концепція пояснює механізм формування нових знань завдяки інтеграції послідовно здійснюваних навчальних дій (дія 3 об’єктом у матеріальному вигляді, дія як зовнішньомовленнєва діяльність, зовнішня мова про себе, внутрішня мова як акт думки), об'єктивна інформація з навколишнього світу стає надбанням свідомості учня.

Концепція не надає психологічного пояснення процесу синтезу знань, утворення зв'язків їх систем у процесі знання.

На вияв інтеграційних процесів спрямована розроблена Ю. Самаріним [5] психофізіологічна теорія асоціативно-рефлекторної природи розумової діяльності. В основу окресленої теорії про асоціативне мислення покладено твердження автора про те, що будь-яке знання $\epsilon$ асоціація, а система знань $\epsilon$ система асоціацій (асоціація в перекладі 3 латинської значить - поєднувати). Відповідно до запропонованої класифікації асоціації, які виникають у процесі навчання, поділяються на кілька видів, які поетапно ускладнюються: локальні, власне системні, внутрісистемні та міжсистемні.

До локальних асоціацій автор відносить найпростіші зв'язки, утворені в межах цих фактів, очевидно, що в цьому випадку інтегративні зв'язки $€$ найбільш простими, які не розкладаються на елементарні.

На рівні системних асоціацій, названих Ю. Самаріним власне системними, асоціації виникають на підгрунті вивчення матеріалу конкретної теми чи предмета, явища, коли вивчення нових фактів i понять супроводжується порівнянням 3 одержаними раніше даними, отже відбувається найпростіше узагальнення знань, але вони не співвідносяться з суміжними знаннями. на цьому рівні виникає аналітикосинтетична діяльність учнів.

Інтеграційні зв'язки, утворені між розділами навчального предмета, курсу, які відображають причиново-наслідкові, часові, кількісні зв'язки, коли відбувається широке застосування знань у межах навчального предмета, який вивчається, названі внутрішньо системними асоціаціями, які забезпечують пізнання цілісних систем знань (біологічних, фізичних тощо).

Вищим рівнем системних асоціацій, а отже, і вищим ступенем розумової діяльності, є зв'язки між матеріалом різних навчальних предметів чи - міжсистемні асоціації, вони об'єднують, узагальнюють різні системи знань, надають змогу пізнати явище чи процес у його розмаїтті. На рівні цих асоціацій виникають загальні поняття, створюються умови встановлення взаємозв'язків на стику різних галузей знань. Отже, відслідковано динаміку розвитку інтеграції асоціацій локальні і власне системні асоціації служать підгрунтям утворення внутрішньосистемних, а ті у свою чергу утворюють міжсистемні. 
Дані психологічні посилання, на думку Ю. Колягіна, О. Алєксеєнко [3], Ю. Кустова, Ю. Кустова [4], надають змогу визначити основні риси можливої інтеграції навчання у школі. Ю. Самарін підкреслює, що в початковій школі, виходячи 3 теорії асоціативного мислення, інтеграція повинна мати кількісний характер - «потроху про все», діти, одержуючи все нові й нові уявлення про поняття, систематично доповнюють і розширюють коло знань, які вже $\epsilon$ ) рухаючись у пізнанні за спіраллю) [5].

Наявність локальної асоціації, характерної для молодшого шкільного віку, а також можливість початку формування власне системних асоціацій є психологічною основою інтеграції в початковій школі.

Як показав аналіз літератури, на сучасному етапі в жодному педагогічному словнику, педагогічній енциклопедії чи довіднику немає сформульованого визначення поняття «інтеграція», хоча в педагогічній, методичній літературі широко використовується надзвичайно велика кількість термінів, пов'язаних із коренем слова «інтеграція», наприклад, інтегровані й інтегративні курси, інтегроване навчання, інтегрований урок тощо. Нині $є$ низка спеціальних наукових праць із педагогіки, у яких сучасні науковці роблять спроби дати визначення феномену педагогічної інтеграції:

- інтеграція - «система органічно пов'язаних навчальних дисциплін, побудована за аналогією $з$ навколишнім світом». В основу інтеграції покладено аксіому, що все у світі взаємопов’язане і не існує в «чистому вигляді» (О. Гілязова);

- інтеграція - «рух системи до великої органічної цілісності» (І. Яковлєв);

- інтеграція - «процес наближення і зв'язку наук, який відбувається поряд iз процесами диференціації, становить собою високу форму втілення міжпредметних зв'язків на якісно новому ступені навчання» (Н. Сердюкова);

- інтеграція - «провідна форма організації змісту освіти на підставі загальності і єдності законів природи, цілісності сприйняття суб'єктом навколишнього світу»;

- інтеграція - «цілеспрямоване об'єднання, синтез певних навчальних дисциплін у самостійну систему цільового призначення, спрямовану на забезпечення цілісності знань і вмінь» (В. Сидоренко).

Очевидно, що більшість педагогів спирається на процесуальні характеристики явища педагогічної інтеграції.

Більш повно поняття інтеграції в педагогіці, на наш погляд, надає В. Безрукова. На іiі думку, можлива побудова визначень педагогічної інтеграції на різних підставах:

- педагогічна інтеграція - вища форма взаємозв'язку (розділів освіти, етапів освіти), якій властиві нерозривність компонентів, нова об'єктивність - монооб'єкт, нова структура, нові функції об'єктів, які вступають у зв'язок. (Підстава для визначення - специфічні характеристики інтеграції як вищої форми взаємозв'язку);

- педагогічна інтеграція - це вища форма вираження єдності цілей, принципів змісту, форм організації процесу навчання і виховання, які здійснюються в декількох розділах освіти, спрямована на інтенсифікацію системи підготовки учнів. (Підстава для визначення - зміст освіти);

- педагогічна інтеграція - це створення укрупнених педагогічних одиниць на основі взаємозв'язку різних компонентів навчально-виховного процесу кількох розділів підготовки учнів. (Підстава для визначення - поняття укрупнених педагогічних одиниць).

Об'єктивна теоретична оцінка ознак, виділених шляхом проведеного вище зіставлення надає нам підстави вивести своє визначення «інтеграції» в педагогіці. 
Органічна інтеграція в педагогічних процесах вимагає врахування того, що ефективність процесу і якість результату залежить не тільки від структурних зв'язків компонентів, але і взаємодії їх потенційних можливостей, інтересів, мотивів і навіть настрою об'єкта і суб'єкта педагогічної системи.

При цьому суперечливий характер самої взаємодії рівною мірою може призвести як до позитивних, такі і негативних чи нейтральних результатів.

Сутність взаємодії може бути розкритою повністю, якщо поєднати структурні доцільно організовані зв'язки 3 енергетичним запасом спрямованості людини на майбутню чи перспективну справу. Інакше кажучи, в педагогічних системах мета та умови створюються ніби зовні. але вони повинні спонукати педагога і учнів до власних цілей, які у свою чергу інтегруються в більш загальне прагнення, яке зумовлює взаємні зміни і розвиток.

Педагогічна інтеграція - це структурний доцільно організований зв'язок однотипних частин і елементів змісту, форм і методів навчання в межах освітньої системи, яка веде до саморозвитку учнів.

Стосовно системи початкового навчання поняття «інтеграція» може мати кілька значень:

По-перше, це створення в учня цілісного уявлення про навколишній світ (інтеграція розглядається як мета навчання). Результат такої інтеграції- учень одержує ті знання, які відображають пов'язаність окремих частин світу як системи, дитина $з$ перших кроків уявляє світ як єдине ціле, уякому всі елементи перебувають у тісному взаємозв'язку.

По-друге, це відшукування спільної платформи зближення предметних знань (тут інтеграція - засіб навчання). На стику традиційних предметних знань, які вже $\epsilon$, діти одержують все нові й нові уявлення про явища навколишнього світу, систематично доповнюючи їх і розширюючи (рухаючись у пізнанні по спіралі).

По-третє, як результат - розвиток учнів, інтеграція в навчанні характеризується діалектичним характером сучасного наукового стилю мислення. Для учнів спостереження об'єкта, який вивчається, не залишається ізольованим елементом. Учень, порівнюючи, будуючи умовисновки, мислить розгляданий об'єкт у різнобічній сфері уявлень i понять, які актуалізуються завдяки різнобічному сприйманню предмета. Встановлення зв'язків між різними формами мислиннєвих процесів i предметних дій забезпечує цілісність діяльності учнів, її системність.

Наукові дослідження в галузі психології і педагогіки надають нам змогу стверджувати, що навчання побудоване на ідеях інтеграції, не тільки можливе, але й обгрунтовано необхідне, особливо для молодшого шкільного віку.

Оскільки ми 3'ясували, що інтеграція - це звичайне обєднання частин в ціле, а система, яка зумовлює кількісні і якісні зміни, логічно, що вона повинна мати різні рівні. 3 питання визначення рівнів педагогічної інтеграції у педагогів думки розходяться.

Так, В. Аберган установлює такі рівні інтеграції в навчальному процесі:

- міжпредметні зв'язки;

- дидактичний синтез;

- цілісність.

Такої ж трирівневої градації інтегративного процесу дотримується Ю. Тюнників. Він виокремив низький (модернізація процесу навчання тільки відносно його змісту), середній (комплексування компонентів процесу навчання) і високий (синтез цілісного новоутворення) рівні. 
І. Коложварі, Л. Січеникова розмежовують чотири рівні інтеграції:

- інтенсифікація пізнавального інтересу i процесу вироблення загальнонавчальних умінь на інтегрованому курсі;

- об'єднання понятійно - інформаційної сфери навчальних предметів;

- порівняльно-узагальнювальне вивчення матеріалу;

- самостійне зіставлення фактів, встановлення зв'язків і закономірностей між явищами і подіями. застосування спільно вироблених навчальних умінь.

Як бачимо, ці виокремлені рівні різняться різними підходами $і \epsilon$ багатоаспектними. Ми вважаємо, що різне виокремлення рівнів у педагогічній інтеграції відбувається від змішування понять двох термінів «зміст освіти» і «зміст навчання», які широко використовуються в педагогічній літературі в останні десятиліття. Різниця між ними зумовлена відмінністю власне понять «освіта»і «навчання».

Оскільки освіта - особистісний здобуток людини, сукупність змін, які відбуваються в ній у результаті ії власної активності, які виражаються в оволодінні системою знань, умінь і навичок, досвідом творчої діяльності, в сформованості світогляду, розвитку якостей особистості, той зміст освіти - це той задатний (бажаний) результат, який сформульовано в Державному освітньому стандарті у вигляді вимог до знань, умінь і навичок.

Зміст навчання $\epsilon$ стосовно до змісту освіти становить засіб стосовно до мети. У якості змісту навчання виступають навчальна інформація і комплекс завдань і вправ, які забезпечують у сукупності потенційні можливості засвоєння певної системи знань. У згорнутому вигляді зміст навчання подано у вигляді навчального плану, більш розгорнуто - в навчальних програмах, повно - підручниках, навчальних посібниках, дидактичних матеріалах, у повідомленні навчальної інформації викладачем.

На наш погляд, виокремлення рівнів у педагогічній інтеграції повинне бути одо аспектне. У межах дослідження розглянемо виокремлені педагогами рівні інтеграції змісту навчання.

Так, становить інтерес підхід розглядуваного педагогічного явища доктора педагогічних наук В. Фоменка. Вивчаючи інтеграційні процеси в школі, він виокремлює мінімальний рівень інтеграції змісту - це рівень традиційних міжпредметних зв'язків, «фрагментарного характеру, так i значного взаємопроникнення, різноякісних систем змісту», високий рівень інтеграції визначається «органічним злиттям, глибиною взаємопроникнення різнорідних і досить крупних масивів змісту» [6]

Також дворівневу інтеграцію бачить Т. Браже [2]. На іiі думку, інтеграція може бути внутріпредметною i міжпредметною. С. Шпильова вважає, що до такої класифікації варто додати позапредметну інтеграцію. [5]

Окрім рівнів інтеграції в педагогіці виокремлюються і іï види. В. Фоменко, А. Катомків, І. Кошміна розрізняють горизонтальне і вертикальне інтегрування. Під горизонтальним інтегруванням мається на увазі поширений спосіб об'єднання подібного змісту низки предметів; під вертикальним інтегруванням - об'єднання матеріалу, який повторюється в різні роки, об'єднання певною темою виховання.

Нам видається, що інтеграційні процеси виявляються на трьох рівнях: внутріпредметному, міжпредметному, міжсистемному i, як відмічає В. Фоменко, 3 високим чи слабким ступенем інтеграції, що суттєво впливає на відбір змісту, так і на конкретні технології вчителя. 
Рівні інтеграційного змісту навчального матеріалу

\begin{tabular}{|c|c|c|c|}
\hline & Рівні & $\begin{array}{c}\text { Змістовний відбір i } \\
\text { структурування } \\
\text { навчального матеріалу }\end{array}$ & $\begin{array}{r}\text { Особливості побудови } \\
\text { самого процесу навчання }\end{array}$ \\
\hline 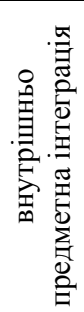 & $\begin{array}{l}\text { високий } \\
\text { ступінь } \\
\text { інтеграції }\end{array}$ & 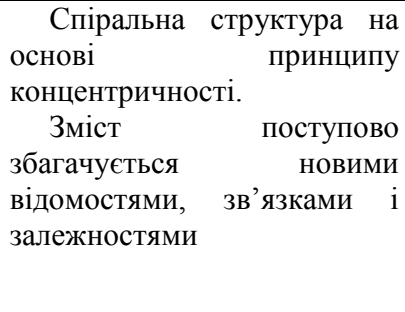 & $\begin{array}{l}\text { Особливості - висхідна } \\
\text { проблема, не зникає } 3 \text { поля } \\
\text { зору учнів, розширюється } \\
\text { коло пов'язаних } 3 \text { нею } \\
\text { знань. Відбувається } \\
\text { більше } \\
\text { співвідношення елементів, } \\
\text { поглиблення пізнання. }\end{array}$ \\
\hline 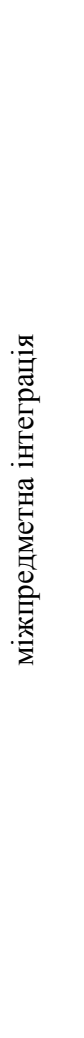 & $\begin{array}{l}\text { міжпредметні } \\
\text { зв’язки } \\
\text { (слабкий } \\
\text { ступінь } \\
\text { інтеграції) }\end{array}$ & 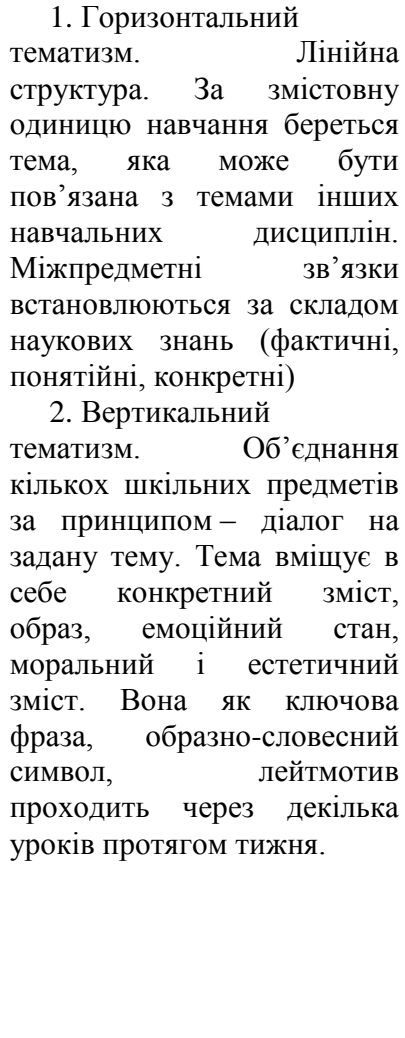 & 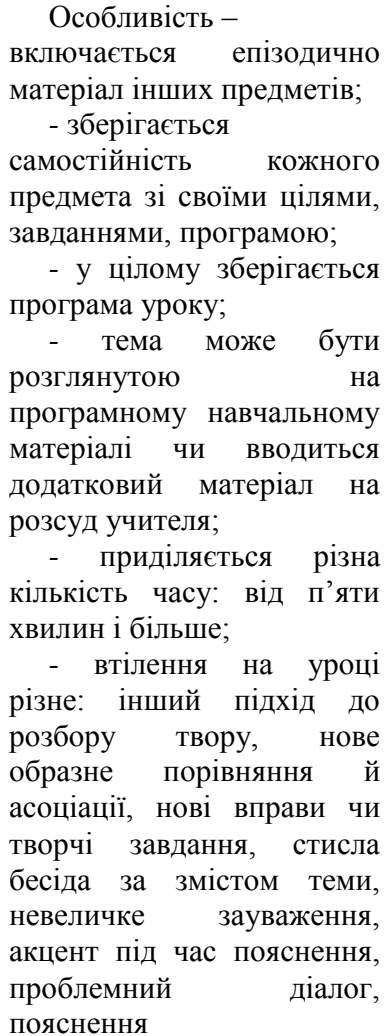 \\
\hline
\end{tabular}




\begin{tabular}{|c|c|c|c|}
\hline 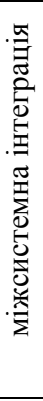 & $\begin{array}{l}\text { інтегрований } \\
\text { урок (середній } \\
\text { ступінь } \\
\text { інтеграції) }\end{array}$ & $\begin{array}{l}\text { Горизонтальний } \\
\text { тематизм. } \\
\text { Змішана структура. Різні } \\
\text { форми організації змісту: } \\
\text { - пластоподібна; } \\
\text { - спіралеподібна; } \\
\text { - заємопроникаюча; } \\
\text { - контрастна; } \\
\text {-індивідуально- } \\
\text { диференційована (творча) }\end{array}$ & $\begin{array}{l}\text { Особливість- } \\
\text { предметом аналізу } \\
\text { виступають багатопланові } \\
\text { об'єкти, інформація про } \\
\text { сутність яких міститься в } \\
\text { різних навчальних } \\
\text { дисциплінах; } \\
\quad \text { - зберігається } \\
\text { самостійність кожного } \\
\text { предмета зі своїми метою, } \\
\text { завданнями, програмою }\end{array}$ \\
\hline & $\begin{array}{l}\text { інтегрований } \\
\text { курс (середній } \\
\text { ступінь } \\
\text { інтеграції) } \\
\\
\text { (високий } \\
\text { ступінь } \\
\text { інтеграції) }\end{array}$ & 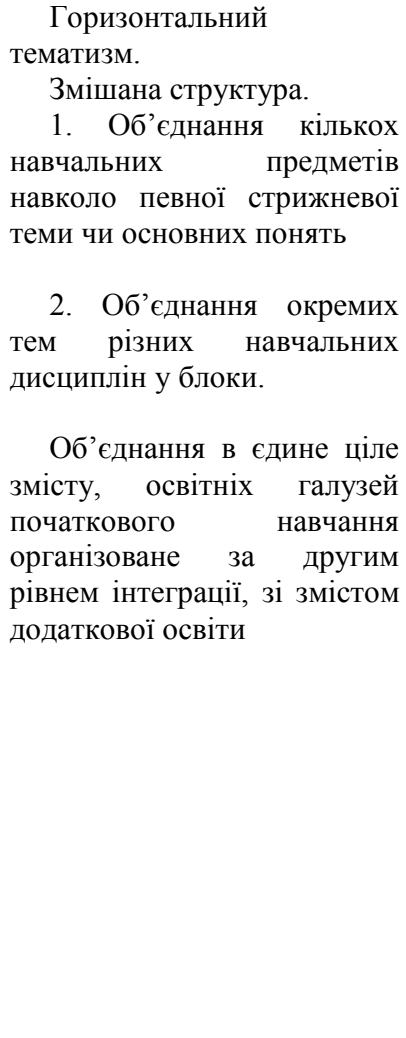 & 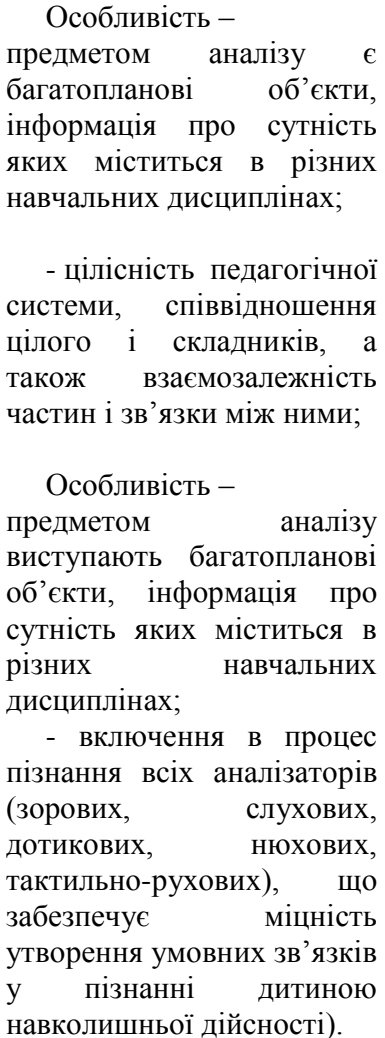 \\
\hline
\end{tabular}

Інтеграція здатна розв'язувати чисельні проблеми освітянської системи. Звичайно, система інтегрованого навчання ще недостатньо опрацьована, а тому неоднозначно сприймається багатьма педагогами. Ї̈̈ повне теоретичне обгрунтування та запровадження у практику навчання - справа майбутнього. Але вже нині $\epsilon$ очевидним, що інтегроване навчання як ніяке інше закладає нові умови діяльності викладачів та учнів, є чинною моделлю активізації інтелектуальної діяльності та розвиваючих прийомів навчання. Інтеграція зобов'язує до використання 
різноманітних форм викладання, що має великий вплив на ефективність сприйняття учнями навчального матеріалу, вона стає для всіх іiі учасників - викладачів, i учнів, i батьків, і адміністрації- школою співпраці та взаємодії, що допомагає разом просуватися до спільної мети. Сучасна педагогічна наука вважає інтеграцію одним із головних дидактичних принципів.

Підсумовуючи наукові дослідження з проблем інтеграції елементів змісту освіти, зазначимо, що у процесі виховуючого навчання необхідно поступово забезпечити у молодших школярів цілісну систему знань про навколишню дійсність. Окрім відомих нині науці фактів, доцільно ознайомити їх із систематизацією наукових понять відповідно до розвитку науки, навчити їх на доступному рівні виокремлювати в єдиній системі знань фундаментальні знання та зв'язки, забезпечити наступність знань та акцентування на перспективних напрямах їх застосування.

\section{Література}

1. Бех І. Інтеграція як освітня перспектива/ І.Бех // Початкова школа. - 2002. № 5. - С. 5-6. 2. Браже Т. Г. Интеграция предметов в современной школе / Т. Г. Браже // Література в школе. - 1996. - № 5. - С. 150-154. З. Колягін Ю. М. Інтеграція шкільного навчання / Ю. М. Колягін, О. Л. Алєксєнко // Початкова школа. 1990. - № 9. - С. 28-32. 4. Кустов Ю. А. Интеграция как педагогическая проблема / Ю. А. Кустов, Ю. Ю. Кустов // Интеграция в педагогике и мире: [сб. науч.-метод. работ]. Самара, 1994. - С. 7-17. 5. Самарин Ю. А. Очерки психологии разума. Особенности умственной деятельности школьников / Ю. А. Самарин. - М., 1962. - 504 с. 6. Тализина Н. Ф. Управление процессом усвоения знаний : психологические основы / Н. Ф. Тализина. - М. : Изд. Моск. ун-та, 1984. - 344 с. 